\title{
The Christian woman as a weaker, but honoured vessel (1 Pt 3:7): Forbidden to act in persona Christi
}

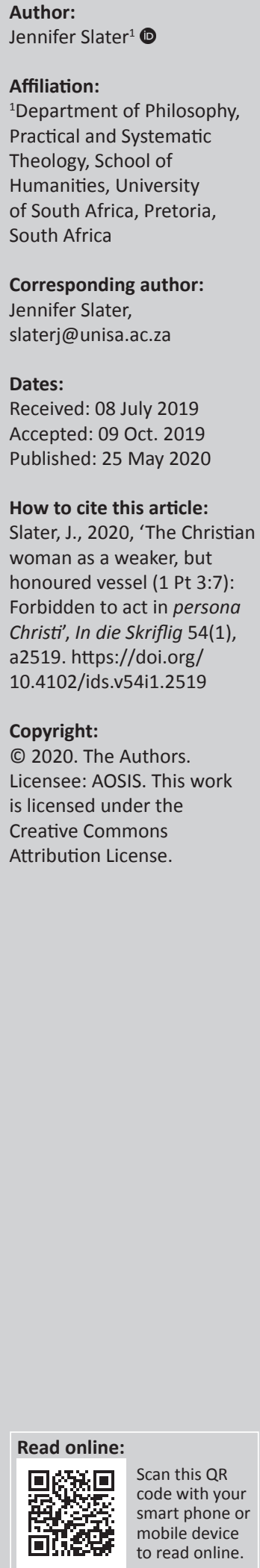

This article presents a Christian liturgical leader as an empty, but useful vessel whose strength is made perfect by the reliance on God's grace. The word vessel is often used in the Bible, and in English terms it translates to be either a container such as a bowl or a jug, or either a ship or a boat. The biblical meaning denotes a person whom God calls and uses as a vessel. The metaphor of a leader as a useful vessel, refers to a person that is receptive. Paul in 2 Timothy 2: 20-21 clearly proclaims that vessels come as useful ones and not so useful ones; some bring honour and others dishonour - the choice belongs to each individual and is illustrated in 2 Corinthians 4:7: ' $\ldots$ but we have this treasure in earthen vessels, that the excellency of the power may be of God, and not of us'. While the task of Christian liturgical leadership is ambiguous and complex, this article refers to someone called to exercise authority and leadership in the way as Jesus called Paul, namely as 'a chosen vessel of Mine to bear my name before Gentiles, kings, and the children of Israel' (Ac 9:15). On the flip side, this brings in a challenging equation of 1 Peter 3:7 where the woman is termed 'the weaker vessel' that 'should be honoured ...'. From this perspective, this article explores what impact this problematic passage has on women's liturgical leadership and practice, especially in the Roman Catholic ecclesiastical culture. It presents a functional biblical vision derived from an understanding that leaders are the vessels that God calls and uses, and that they are guided by a biblical spirituality of leadership. This leadership is consistent with the democratic tradition within Christianity that emphasises dialogue with the Holy Spirit.

Keywords: biblical leadership; liturgical leadership; chosen vessel; empty vessel; persona Christi; Magisterium; Sacrament of Holy Orders.

\section{Introduction}

The article attempts to provide a functional biblical vision of a Christian liturgical leader that derives from an understanding that leaders are vessels that the Almighty calls and uses in various competencies. For Christian leaders, regardless of their gender, without doubt, there exists the need to be guided by a biblical spirituality that is consistent with the open tradition within Christianity that requires the prayerful invocation and guidance of the Holy Spirit. The metaphor of a liturgical leader as an empty vessel signifies openness and receptivity to divine authority and to act on behalf of Jesus Christ. Jesus called Paul 'a chosen vessel of Mine to bear my name before Gentiles, kings, and the children of Israel' (Ac 9:15). 1 Peter 3:7 terms a woman as 'the weaker vessel' that 'should be honoured ...'. The article explores some biblical references from the Old and New Testament and the usages of the term vessel together with the associated meanings. The Old Testament includes references such as 1 Samuel 21:5, Isaiah 30:14, Wisdom 14:1 and Ezekiel 8:28. The New Testament exploration depicts references such as 2 Timothy 2:20-21, Romans 9:21-23, 2 Corinthians 4:7, Acts 9:15 and 1 Peter 3:7. The article then focuses specifically on the notion of a Christian leader as an empty, but useful vessel, and discerns the practical and spiritual relevance for current leadership especially in ecclesiastical spaces. Particular attention is assigned to woman leadership, or the lack thereof in liturgical settings where she is perceived as 'the weaker vessel', inferior to the male, based on corporal differences. Distinct focus is rendered to the theological and biblical justifications that are rendered to restrain the woman by maintaining that she cannot lead liturgical and sacramental celebrations, particularly in the Roman Catholic tradition, as she cannot, theologically speaking, lead in the person of Christ (persona Christi) by virtue of being a woman. The article concludes by drawing lessons from Jesus as a vessel that emptied himself (Phlm 2:7-11), a leader who took the form of a servant, being born in the likeness of all humans: male and female.

\section{Biblical leaders as chosen vessels}

Biblical leadership is always connected to a divine calling, related to the will of God to perform a specific task and to take full responsibility thereof. Leaders, be they in the Old or New Testament, 
fall under different categories such as prophetic leaders (Jeremiah or Isaiah), royal or monarchical leaders (Saul and David), power wielders (Pharoah), judges (Deborah), charismatic leaders (David), political conquerers (Nebuchadnezzer), consultative leaders (Daniel), participative leaders (King Cyrus), transformational leaders (Moses), servant leaders (Moses and Jesus), visionary leaders (Nehemiah), missionary leaders (Paul), and courageous leaders (Peter) (Bott n.d.). In the New Testament women leaders also exercised different types of leadership such as liturgical leadership (Phoebe) who functioned as a 'deacon' (Rm 16:1), teaching leadership (Priscilla) who read Paul's letter to the assembly (Ac 201:26), business leader (Lydia) who excelled in hospitality (Ac 16:14-15; 16:40) and apostolic leadership (Junia) in Romans 16:7.

The concept vessel, represents a functional biblical vision derived from an understanding that leaders are the vessels that God calls and uses, and that they are guided by a Yahweh spirituality that empowers them. Yahweh spirituality can be summed up in the words of Albert Einstein who said: 'I want to know God's thoughts ... the rest are details' (Salaman 1955), which implies discerning the mind and very heart of God, and to build one's life mission and vision on such knowledge. The calling of a biblical leader is housed in a vision that is twofold in meaning. The first is that leadership without vision, without a plan, causes people to function aimlessly; and the second biblical meaning of the vision is that those called to leadership received revelations whereby the word of God was communicated to them. The visionary encounter of God came either in the form of dreams, or as direct experiences such as in 1 Samuel 13:1, or Moses in Exodus 3:1-15, Daniel in Daniel 6, or Paul in Acts 9:1-22. Where there was a lack of vision, there existed a deficiency of God's word and leadership. Vision can therefore refer to a form of divine communication that comes in dreams, or in the form of transcendent communication or direct encounters with the divine. It is for this reason that the biblical vision of leadership is summed up in the axiom: 'Where there is no vision, the people perish' (Pr 29:18). The biblical vision of leadership is grounded on the reliance that, without God, nothing is possible. Biblical leaders often had to minister, address or lead people out of certain turbulent political and social situations, and they performed their leadership in conjunction with the discernment of Yahweh's will and law. Their assignments stemmed from an intimate relationship with Yahweh as well as an understanding of the requirements of Yahweh's covenant. They often had to confront the social transgressions of political and royal leaders who contravened Yahweh's covenant when they oppressed the poor, exploited workers and extorted the defenseless often by means of bloodshed. They had to challenge the Israelites religious transgressions and infidelity to Yahweh's laws and commands. Leaders had to come to the rescue of the people of God, not only when they were in crisis, but also to enable them to act and challenge unjust situations. Biblical leaders had to be transparent regarding their relationship with
Yahweh, and voice their values and beliefs, however, in the words of Brown (1970:1111), love is the primary quality which Jesus looks for in a leader (Jn 21: 15-19).

Virtually all the circumstances that the leaders in both Old and New Testament experienced, are repeated in different forms throughout history and in contemporary times. The prophet leaders witnessed as much turbulence and experienced national calamities that forced them to call on the Divine for intervention and guidance. Notably, the spirituality of their leadership was deeply rooted in Yahweh, and they were often called to discern God's presence and direction in adverse situations. For example in the case of the prophet Jeremiah when the Babylonians threatened to invade Jerusalem and Judea; when many Judean officials were taken captive and into exile; when Jerusalem was actually captured in 587/586 BCE and when King Zedekiah and many priests were arrested (Jr 20-22; 24-29; 32; 34-45). Jeremiah had to listen and discern what Yahweh's designs were (Wessels \& Barentsen 2016:30). Leaders who came in the form of judges or prophets chosen by Yahweh, were vessels to help the Hebrews through their struggles. When the Hebrews asked God for special leaders, such as their request for an earthly king to rule them, God granted them a king, but their king was not to be like other kings. God required that their king should be obedient unto the will of Yahweh, as Yahweh was the real leader. The kings acted in the place of Yahweh. Saul was the first leader as king, and he was anointed by the prophet Samuel. Saul was a vessel that had to be used and filled by God alone (1 Sm 9). The calling of the leader (as a chosen vessel) is situated in a relationship with Yahweh that is based on deep reverence and humility such as testified within Psalms 19:9 where David says that the fear of the Lord is pure, and he refers to himself as God's servant (Ps 19: 13). He also calls Yahweh his Lord, his Rock and his Redeemer (Ps 19:14). The leader's obedience to God is in the keeping of God's Word that flows from a relationship in which the leader feels loved by God and loves God in return (1 Jn 4:7-10).

Christian leadership is complex and refers to someone that is called to exercise authority and leadership in the way as Jesus called Paul: 'a chosen vessel of Mine to bear my name before Gentiles, kings, and the children of Israel' (Ac 9:15). Leadership in the Gospels was housed in the person of Jesus Christ. He was the leader and the one who exercised leadership. On various occasions in the four Gospels, Jesus sent his disciples to certain places and his disciples obeyed. In the Acts of the Apostles and the Epistles, Peter and Paul acted as leaders, but they did not claim to send anyone anywhere to do the work; the going-out workers were sent by the Holy Spirit. Acts 13:4 tells us that Barnabas and Saul were 'sent out by the Holy Spirit' from Antioch to the Gentiles. Of course, Paul did urge some of the younger brothers, such as Timothy and Titus, to go to certain places and to do certain things (1 Cor 4:17; 1 Tm 1:5). In 1 Corinthians 16:12 Paul commended Apollos; however, he never commanded, and this verse testifies that Paul did not 
exercise any dominion over the work of the Lord. In this sense Paul did not exercise conventional leadership in the Jesus-Movement. He did not control his co-workers, and neither did Peter. Instead, they were more intent on the correct teaching of the apostles. 1 Timothy 1:3-4 testifies to this as Paul urged Timothy to remain in Ephesus and to make sure that no one teaches differently from God's New Testament economy. Even the apostle John, in his second epistle, told the saints not to receive anyone who brings a teaching other than the teaching of Christ (2 Jn 9-10).

Paul and his colleagues did not necessarily emerge as 'ideal leaders'. According to Slater (2012) he was:

[F]ully aware that leaders can be ambiguous, deceitful and sometimes failed in their task stating in 1 Cor 12: 6-27, that they should consider their call ...; since God chose the weak in the world to shame the strong ... (p. 204)

In the effort to establish Paul's position regarding leadership and authority, it is clear from his works, that to be a leader is not to be a 'lonely Christian hero', but to be part of a team (Gl 1:18-19, 23). In Paul's letter to the Galatians, he refers to conflict between himself and the other apostles over positions of power and authority. He claims that 'he is an apostle not from men, nor through man, but through Jesus Christ' (G1 1:1). Leadership was vested in Jesus Christ and with him it was a shared responsibility consisting of co-workers, men and women, such as Timothy and Barnabas, Aquila and Prisca (1 Cor 16:19; Rm 16:3). They were all equal to Paul in leadership and responsibility. There seems to be no evidence that women were excluded from the group of team-workers in Christ, as some were even mentioned as being in leadership regardless of their gender (Rm 16:3; 12). Mary, Tryphaina and Persis (Rm 16:12) were recognised as leaders and appreciated without any reservations within the Christ-movement (Slater 2012:205). Thus, as stated by Ehrensperger (2007):

$[T]$ here are no indications that leadership roles, that is, the exercise of power-over in asymmetrical relationships to communities by women was a cause of concern or problematic within the group of those commissioned, recognised and accepted as being entrusted with special tasks within the movement. (p. 55)

As testified by Lydia and the other women at Philippi, several women became devout believers of the Jesus-Movement, which was called the New Way (Lk 23:27; Ac 16:13-15; 17:12). God gave these women different spiritual gifts in order to equip them for leadership in the church as ministers of the word and ministers of service. Women leaders used the Word to preach, prophesy, evangelise, pastor and teach others in obedience to Christ (Ac 6:2-4; Eph 4:11-13; 1 Pt 4:10-11). Included in this category are the apostle Junia ( $R m$ 16:7), Anna the prophet(ess) (Lk 2:26), and teacher Priscilla (Ac 18:26). Mary Magdalene, Joanna, Mary, the mother of Jesus and Mary, the mother of James and Joseph, and Salome, the mother of James and John were the first witnesses of the resurrection, commissioned to tell the good news.
Women occupied leadership positions as church overseers, as John addresses his second letter to a women overseer and the members of her house church. They were in ministerial leadership such as Phoebe, a minister at Cenchreae, commended by the Apostle Paul to the church at Rome as 'a woman set over others', a 'leader' over many and even 'over' Paul (Rm. 16:1-2). The church at Phillipi was subject to Paul's colleagues (co-workers) Euodia and Syntyche (Phlp 4:2-3 and to Stephana's household 1 Cor 16:15-18), and house churches at Rome and Ephesus were subject to the team ministers Prisca and Aquila who 'risked their lives' for Paul (Rm 16:3-5; 1 Cor 16:19; Spencer 2009:24).

Women were also functional as 'ministers of service', whereby they met the physical and emotional needs of others

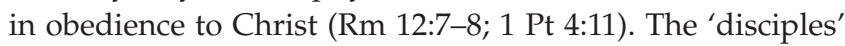
Tabitha or Dorcas was such an effective minister of service that the church at Joppa would not allow her to die (Ac 9:36-41). Martha many times oversaw the use of her house as an inn for the stay of Jesus and the disciples (Lk 10:38-40; Jn 12:2). The Order of widows was an order of prayer, which had as one of its prerequisites a ministry of service (1 Tim 55-10). Lydia, a successful career woman (a seller of the royal purple dye), took a leadership role in the new church at Phillipi while offering hospitality to Paul, Luke, Silas and Timothy (Ac 16:14-15, 40). Mary Magdalene, Joanna, Susanna, and many other women disciples provided for the economic needs of Jesus (Mt 27:55; Mk 15:41; Lk 8:2-3). They denied themselves by giving generously to Jesus' mission (Spencer 2009:24). It is obvious that the New Testament women were exemplary models of the Christian life and the leadership of the church. They were devoted followers of Jesus and were effectively employed by the Holy Spirit in the service of the gospel of Jesus Christ.

\section{The biblical concept of leaders as 'empty, useful vessels'}

The leader as a vessel, an empty, but useful vessel, refers to a person that is receptive and ready to be filled by the Spirit and the power of God. The concept vessel appears several times in the Bible in various ways and with different connotations. In some cases a vessel is referred to as being a utensil such as in 1 Samuel 21:5 or a holy object. In 1 Samuel 21:8 the term denotes a weapon and in Isaiah 30:14 it is a jar or a pot. According to the Wisdom of Solomon 14:1, a vessel is a boat and in Solomon 14:5, 6 the vessel is in fact a weak boat. Ezekiel 8:28 refers to vessels as holy utensils; they were made of precious material such as gold and silver and in Numbers 5:17, they were made of earthenware and can contain water, whereas in Kings 25:14 they are referred to as pots, shovels and spoons made of bronze and used in the temple service. Vessels became special utensils that were used in the temple and in the houses of the kings and nobility. There is, however, an additional meaning concerning the biblical use of vessels as they became natural illustrations for different sorts of human beings as were portrayed in Hosea 8:8, Isaiah 22:24 and Jeremia 22:28. In Hosea 8:8, Israel is swallowed up! Now they are among the nations like a worthless vessel. When it comes 
to the New Testament, as illustrated in Acts 9:15, the word vessel has passed into Christian theology as simply signifying a human being (ISBE). As is conveyed in Romans 9:21 and 23, the human person is a 'vessel of God':

${ }^{21}$ Hath not the potter power over the clay, of the same lump to make one vessel unto honour, and another unto dishonour? ${ }^{22}$ What if God, willing to shew his wrath, and to make his power known, endured with much longsuffering the vessels of wrath fitted to destruction: ${ }^{23} \mathrm{And}$ that he might make known the riches of his glory on the vessels of mercy, which he had afore prepared unto glory, ${ }^{24}$ Even us, whom he hath called, not of the Jews only, but also of the Gentiles?

The human person is symbolised as a vessel of God. In this instance the vessel is a container, which is different from a utensil or an instrument. This vessel is meant to contain God. The potter in Romans 9 desires that the human, as a vessel, is to contain God himself. The potter (God) created vessels in God's honour, glory and mercy, and the human vessel is unto God.

The same idea is furthered in 2 Timothy 2:20-21:

${ }^{20} \mathrm{But}$ in a great house there are not only vessels of gold and silver, but also of wood and clay, some for honour and some for dishonour. ${ }^{21}$ Therefore, if anyone cleanses himself from the latter, he will be a vessel for honour, sanctified and useful for the Master, prepared for every good work.

It is clear that some vessels are useful and others not so useful; some bring honour and others dishonour - the choice belongs to each individual. All the same, while the human body is frail like an earthen vessel, the excellence of the power vested in the authority or leadership comes from God, and not from humans as is illustrated in 2 Corinthians $4: 7:$ '. . . we have this treasure in earthen vessels, that the excellency of the power may be of God, and not of us'.

The metaphor of the earthen vessel, although weak or fragile, is filled with treasures and Christ is the treasure and the Apostles as leaders, minister Christ who is the treasure that is stored within humans. The 'we' here refers to the apostles, ministers of Christ and all believers. The 'treasure' is the gospel and the 'earthen vessels' is the frail human being, but vessels in which the treasure is housed and upon which value and dignity are conferred. Ananias reminded the Lord that Saul was a notorious person who persecuted the Christians, but Jesus Christ was adamant that Ananias, as a leader, must go his way and tend to Paul who was a chosen instrument or vessel with the task to be an Apostle to the Gentiles (Ac 9:15). Despite Paul's previous tarnished reputation, the most valuable treasure can also be deposited in him.

\section{The woman is termed 'the weaker vessel'}

While the term vessel, a useful vessel, presents a positive and functional biblical vision of the understanding that leaders are the instruments that God calls and uses, it brings into a challenging equation 1 Peter 3:7, where the woman is termed 'the weaker vessel' that 'should be honoured ...'.
Likewise, husbands, live with your wives in an understanding way, showing honour to the woman as the weaker vessel, since they are heirs with you of the grace of life, so that your prayers may not be hindered. (1 Pt 3:7)

Fundamentalist interpretations that single out the words the woman as the weaker vessel had many contrary consequences on the overall status of women. The rhetorical effect of the term weaker was often misused despite the fact that Peter juxtaposed it with the phrase bestowing honour. Peter's view of household leadership from the perspective of the patriarchal masculine role, which was connected to the happiness of the wife, was a prerequisite of good patriarchy proper to his time. This sentiment is affirmed by Paul in Ephesians 5:23-29 where husbands are presented as the sacrificial head of their wives in leadership, protection and initiative. The question is whether Peter use the word weaker vessel to refer to the social disadvantages that women experienced in his day, because in 1 Corinthians 1:27, Paul also uses the Greek word asthenēs, ${ }^{1}$ although he refers to weaknesses in society: God chose the weak of this world to shame the strong. The social weaknesses of the time did, however, disadvantaged women in the sense that they were not advanced in education, did not have social influences, neither wealth or possessions. What is apparent, is that Peter juxtaposed the phrase weaker vessel with the phrase bestowing honour (1 Pt 3:7) and by so doing he redeems himself:

${ }^{7}$ In the same way, your husbands must give honour to your wives. Treat your wife with understanding as you live together. She may be weaker than you are, but she is your equal partner in God's gift of new life. Treat her as you should so your prayers will not be hindered.

Peter states that the woman is an equal partner. This is a strong plea for mutuality and equality of men and women within marriage. This, nevertheless, leads to an additional question: Does the 'weaker vessel' refer to wives only, or does it refer to women as a whole?

The fact remains, while in biblical times women were economically, legally, politically, socially and culturally disadvantaged, it is still not much different today. The power of this passage still has an adverse effect on the contribution women bring to leadership wisdom, as their capacity to lead is still viewed with the weight of scepticism, especially in clerical, ecclesiastical and social circles. Women in religious and liturgical settings are still considered weaker vessels, and the basis to exclude them or keep them on the periphery of leadership positions.

\section{Women as the weaker vessel (1 Pt 3:7), and the forbidden claim to persona Christi}

While women can be in service of various academic and administrative positions in the Roman Catholic Church, their exclusion from ordained, liturgical leadership is still a matter 1.This entry on asthenēs comes from the LSJ Greek-English Lexicon (Liddell, Scott \&
Jones 1996 [1843]). It gives the primary meanings as 'without strength' and 'weak', and it lists other kinds of weaknesses, not just physical or bodily weakness. 
of ineffectual debate. The theological debates over the admittance of women to ordained leadership is a locked topic, and scriptural texts that are bound to ancient biblical culture are still used to bolt the door. 1 Timothy 2:12-14 is, for example, such an exploited text:

${ }^{12}$ And I do not permit a woman to teach or to have authority over a man, but to be in silence. ${ }^{13}$ For Adam was formed first, then Eve. ${ }^{14}$ And Adam was not deceived, but the woman being deceived, fell into transgression.

According to Wijngaards (2001:8), this was written in the context of a Gnostic threat to which women were considered especially vulnerable. Wijngaards (2001:8) claims that this is not inspired scripture, but a cultural interpretation imposed upon Scripture. Nine such scripture passages had been used to exclude women from ordination inter alia Genesis 2:18-23; 3:16; Sirach 25:13-24; Matthew 9:20-22; Luke 7:37ff.; John 8:11; 1 Corinthians 11:2-16; 14:35-35; 1 Timothy 2:12. He concludes that cultural prejudice, rather than God's will, is therefore responsible for women's exclusion from ordained ministry and leadership.

For many centuries in the past, women served in a number of ministerial leadership positions, which included sacramental diaconate. Numerous women feel called by God to ordained liturgical and pastoral leadership and there exist many priestly vocations among women, but they were always and still are barred from the sacrament of ordination. The Catholic Church claims that Jesus himself 'excluded' women by choosing male persons as the apostles, and the magisterium claims that they honour this tradition, as women cannot represent Jesus who was a man. Currently the Roman Catholic Church only ordains men as deacons and priests, as both offices form part of the clerical structure. This is so despite the fact that Jesus, in his earthly life, never ordained anyone. Jesus called his disciples to leadership, but he did not ordain them priests. The teaching on ordination, as it appears in the Code of Canon Law, the Catechism of the Catholic Church, and the Apostolic letter on Ordinatio Sacerdotalis, states that only a baptised man (vir in Latin) can validly receive the Sacrament of Holy Orders (Code of Canon Law, \#1024).

The exclusion is based on gender and on the physical appropriateness of maleness. Because the physical appearance of the woman is not 'correct', the theological argument that is put forward, is that the woman cannot function in persona Christi. This theological argument has a long history and is primarily used today to exclude women. The theological notion that the priest truly acts in the 'person of Christ', was introduced by Saint Cyprian in the 3rd century. The Declaration 'Inter insigniores': On the question of the admission of women to the ministerial priesthood published by the Congregation for the Doctrine of the Faith in October 1976 reads:

The supreme expression of this representation is found in the altogether special form it assumes in the celebration of the Eucharist, which is the source and centre of the Church's unity, the sacrificial meal in which the People of God are associated in the sacrifice of Christ: the priest, who alone has the power to perform it, then acts not only through the effective power conferred on him by Christ, but in persona Christi, taking the role of Christ, to the point of being his very image, when he pronounces the words of consecration. (Seper \& Hamer 1976:2)

The document states that despite in our time 'women have an ever more active share in the whole life of society, it is very important that they participate more widely also in the various sectors of the Church's apostolate', the priestly or episcopal ordination remains out of bounds for women. The document Inter insigniores claims that:

Jesus did not entrust the apostolic charge to women. Even his Mother, who was so closely associated with the mystery of her Son, and whose incomparable role is emphasized by the Gospels of Luke and John, was not invested with the apostolic ministry. (n.p.)

This argument is based entirely on the church and biblical cultural tradition that does not hold value in current civil society that abides by human rights and equal opportunities.

Concerning the celebration of the Eucharist, which is a male prerogative in the Roman Catholic Church and confined to the sacrament of Holy Orders (ordination), the question arises whether it is the maleness of Christ, and therefore the maleness of the priest, that enters the formal structure of the sacrament of the Eucharist.

In the Catholic tradition priesthood is a sacrament and the priest is a sign. The teaching authority of the church explains that the sign must be perceptible and the faithful must be able to recognise it with ease. Sacramental signs, according to Saint Thomas Aquinas and Karl Rahner, 'represent what they signify by natural resemblance'. The Declaration, Inter insigniores, argues that when Christ's role in the Eucharist is to be expressed sacramentally, there should exist a 'natural resemblance' between Christ and his minister. If the role of Christ were not taken by a man, it would be difficult to see in the minister the image of Christ (Seper \& Hamer 1976). The theological interpretation is that the woman is not a correct vessel, sign or instrument and the understanding is that she cannot be the natural resemblance of Jesus Christ as this exist only in a man.

The church therefore claims that Jesus Christ was and remains a man, even in his resurrected state. The critical question, however, remains: Does the priest represent Christ the male or Christ the mediator of saving grace? Does the priest represent Christ the male more when he celebrates the Eucharist than when he celebrates the other sacraments such as baptism or matrimony (Doyle 1983:84)? Is the woman barred from being a priest because the ministry of the Eucharist in persona Christi concerns the maleness of Christ more than the action of baptising a person, because any person can baptise another in the name of Jesus Christ in an emergency? While administering the sacrament of baptism remains the prerogative of a bishop, priest and deacon (canon $861 \S 1$ of the Code of Canon Law) if the ordinary minister is absent or impeded, any person who has the requisite intention may do so, even a non-Catholic, or indeed a 
non-Christian (canon 861 §) and this includes a woman. Why is the maleness of the in persona Christi confined more to the Eucharist and not to the other sacraments? Doyle (1983:84) says that there exists a discrepancy in the argument, because if the priest acts in persona Christi when he pronounces the words of consecration, then the same should hold for the woman as minister of baptism. She also acts in persona Christi when she pronounces the words of baptism. Another important question at stake here is on what theology is this exclusion of the woman based: on the historical Jesus who was male, or the resurrected Christ who, theologically speaking, transcends gender.

A closer examination of Thomas Aquinas' explication when he answered the question whether the female sex is impeded from receiving Holy Orders solely because she is the weaker vessel or sex, is interesting. His reply was that there are certain conditions required by the recipient in compliance of the nature of some sacraments, and other conditions are required by law. Aquinas (1920) argues that the male sex is a condition required by the nature of the sacrament of orders. Because a sacrament is a sign, it requires both the res (what it signifies, grace) and also the signification (significatio rei). He goes further by stating that because it is not possible to signify eminence of grade in the female sex - woman is in a state of subjection - it follows that a woman cannot receive the sacrament of Holy Orders. There is a very subtle distinction here and hence the fact that Aquinas needs to be read in context.

\section{Is it maleness or natural male superiority that excludes women from ordination?}

According to St Thomas, the woman is not barred from ordination just because of maleness, but because of the superiority of the male. The significatio rei, in this case, is not formally maleness (that the priest represents Christ, the Male), but the eminentiagradus. Aquinas' argument does not rest on maleness as such, but on the assumption of the natural superiority of the male to the female and it is this superiority which endows the male with the significatio rei to receive the dignity of the sacrament of orders. So it is not about maleness, but about the superiority of the male. To illustrate this idea of female subjectivity and male superiority, Thomas Aquinas answered the question whether a slave can receive the sacrament of Holy Orders (Ordination). Once again, he says, because the slave (servus) is in a state of subjection, he cannot receive orders, just as a woman being in a state of subjection cannot receive Holy Orders (Aquinas 1920: q. 83, art. 1, ad 3: 33). The reply of Aquinas is based on the theological belief that: 'sacramental signs represent [what they signify] by natural resemblance; a woman, however, is by nature in subjection [to men], but a slave is not [by nature in subjection]' (Aquinas 1920:, q. 83, art. 1, ad 3:34). Once again the issue is not maleness, but the superiority of the male. A woman does not have the required degree of eminence to receive the dignity of the sacrament of orders. Nowhere is the issue precisely about the maleness of Christ. It is rather that the male has $a$ natural superiority and, as such, is capable of acting in persona Christi. For Thomas Aquinas, it is therefore not so much the physical image, but who is endowed with the dignity fit for the priesthood. This theological argument seems to be outmoded, particularly in light of today's 'doctrinally correct' perception of the woman. Despite the contemporary corrective measures concerning the status of women, Pope Benedict XVI (2007:2) still declared that in persona Christi to priestly ordination relates only to men. Many women who feel called to the priesthood are told that they cannot function in persona Christi despite the fact that Paul says in Galatians 3:27 that all the baptised put on Christ. 'For as many of you as were baptised into Christ have put on Christ' (Gl 3:27). This includes both women and men, but the interpretation is not consistent.

By showing that women are not in subjection to men and that men are not superior to women or more eminent, but equal, should the argument of barring women from ordination not fall away as is asked by Doyle (1983:84)? For now Catholic women who genuinely feel called to the liturgical leadership in the form of priesthood continue to suffer the pain of exclusion just because they are women.

\section{Weaker vessels remain excluded from ordained liturgical leadership}

This exclusion had been formally challenged from the beginning of the 21st century. In 2002 several Roman Catholic women took it upon themselves to be ordained as deacons, priests and bishops, and they claimed that their ordinations are valid because their ordinations were administered by a validly ordained Catholic male bishop, Romulo Antonio Braschi, but who has left the ministry in 1975. Consequently, on 02 December 2002, the Congregation for the Doctrine of the Faith issued the Decree on the attempted ordination of some Catholic women. This was issued by the Sovereign Pontiff John Paul II, and signed by the then Prefect of the Congregation for the Doctrine of the Faith, 21 December 2002, Cardinal Joseph Ratzinger. The decree (see Ratzinger 2002) states that those women that were ordained:

\footnotetext{
... would be punished with excommunication if by July 22, 2002, they had not acknowledged the nullity of their 'ordination' and asked forgiveness for the scandal caused to the faithful. As they gave no indication of amendment, this congregation punished the aforementioned persons with excommunication, reserved to the Apostolic See, in the Decree dated Aug. 5, 2002, expressing the hope that they might be moved to conversion. The decree also confirmed that the 'ordaining' bishop was already excommunicated insofar as he is a schismatic. (p. 1)
}

This decree excluded the ordained women even further by means of excommunication. Pope John Paul ll recapped the church's stance as set out in Ordinatio Sacerdotalis, 4, stating again that 'the church has no authority whatsoever to confer priestly ordination on women'. He also endorsed the Code of Canon Law (Canons $750 \$ 2 ; 1372$, n. 1) confirming 'that those who are in denial of this doctrine is rightly considered the denial of a truth that pertains to the Catholic faith and therefore deserves a just penalty'. The ordained women, the so-called 'weak vessels', suffered the most severe form of 
exclusion in the form of excommunication from the church. This means that they are barred from participating in the sacraments and liturgical services.

The act of ordaining women was regarded by the hierarchical church authorities as open and divisive disobedience to the Roman Pontiff and diocesan Bishops. The decree reads:

The above-mentioned members of the Congregation of the Doctrine of theFaith, therefore, confirm the Decree of excommunication issued on Aug. 5, 2002, specifying once again that the attempted priestly ordination of the aforementioned women is null and invalid (cf. Canon 1024) and therefore all those actions proper to the order of priesthood performed by them are also null and invalid (cf. Canons 124; 841). In consequence of the excommunication, they are forbidden to celebrate sacraments or sacramentals, to receive the sacraments and to exercise any function in an ecclesiastical office, ministry or assignment. (cf. Canon 1331 §1)

The women that were ordained all ignored the excommunications writs. From 2002 onwards, women continued to be ordained by women bishops and the excommunication on them was reiterated in 2008 by a debarring order on 29 May. This was published in the Vatican Newspaper, L'Osservatore Roman, a decree signed by Cardinal William Levada, stating that women 'priests' and the women 'bishops' who ordained them (men or women) are automatically excommunicated (latae sententiae), a term used in Canon Law, which means 'already sentenced', already found guilty by virtue of being ordained. The Decree called for the conversion of the women and 'so return to the unity of faith and to communion with the Church, a communion broken by their action' (no. 5 of the degree).

This doctrine and consequent reaction of exclusion were confirmed by Pope Francis in November 2016 when he said that 'that door is closed', pertaining to the priestly ordination of women. He said he affirms the teachings of his immediate predecessors, namely Pope John Paul 11 and Pope Benedict Vl and it will not be tampered with by him. He also holds on to the Petrine dimension, which derives from the Apostle Peter and the Apostolic College, which is the pastoral activity of the bishops. He argues that the Church is portrayed as the Bride of Christ, hence women cannot be priests, hence they cannot become bridegrooms. He did, however, on 20 June 2018 authorised a commission to see if women again could be made deaconesses. Whether this will be accompanied with ordination, remains to be seen. For now, however, ordination of women is perceived as doctrinally not permissible, and Pope Francis states that it is not a 'capricious thing'. So, to ordain women still remains a closed door. While ordination to the priesthood is out, Pope Francis, in the same interview, states that women need to be given more opportunities for 'leadership in the Roman Curia'. ${ }^{2}$ While ordained leadership is not the only type of leadership in the church (or in society), it is important to bear in mind that all Christian leadership, regardless of gender, prominence and category, is guided by the genus and kenotic spirituality of Jesus Christ.

\section{The spirituality of 'kenotic' leadership and relevance to the 'weaker vessel'}

Jesus' leadership epitomises the manner of leadership for all Christians. We have seen that Paul was sent by Jesus as his 'chosen vessel ...' (Ac 9:15), equally so was Jesus sent by the Father, and Jesus' leadership is housed in his mission and obedience to the will of his Father: 'For I have come down from heaven, not to do my own will, but the will of him who sent me' (Jn 6:38).

The nature of this Jesus' leadership in summed up in the gospel of Mark (10:45; see also Mt 20:28): 'For the Son of man also came not to be served, but to serve, and to give his life as a ransom for many.'

For Jesus to be sent by the Father required that:

\begin{abstract}
${ }^{7}$... he emptied himself, by taking the form of a servant, being born in the likeness of humans. ${ }^{8}$ And being found in human form, he humbled himself by becoming obedient to the point of death, even death on a cross. ${ }^{9}$ Therefore God has highly exalted him and bestowed on him the name that is above every name, ${ }^{10}$ so that at the name of Jesus every knee should bow, in heaven and on earth and under the earth, 11and every tongue confess that Jesus Christ is Lord, to the glory of God the Father. (Phlp 2:7-11)
\end{abstract}

Jesus' leadership is characterised by a spirituality of kenosis and true Christian leadership is grounded in the same spirit. The self-emptying of Jesus creates space to receive the divine will of God, the Father. This self-emptying makes way for self-giving and kenotic love, which means turning away from self-centeredness and self-importance. This implies living and leading in communion with God and embrace a leadership that is open to the vision of kingdom leadership. From a Catholic Christological perspective, God, the Father, emptied God-self in the act of creation, Jesus the Son emptied himself in the incarnation, and this self-emptying found total expression on the cross. This kenosis is an act of love and kenotic love, which is self-giving love, overcomes evil and creates salvation (Richardson \& Bowden 1989:316). This self-emptying is not a sign of weakness, but of strength, as it is linked with humility that is glorified in exultation (Phlp 9:9), and fully realised in Jesus' resurrection. Kingdom leadership is not worldly leadership. Jesus preached and lived his vision of kingdom leadership and he expected his disciples and followers to do the same (Adair 2001:133). His leadership was marked by compassion that moved him into action. However, as stated by Adair (2001:134), real compassion is always costly and in Jesus' case it had unforeseen and unfortunate consequences. This self-giving attribute was acknowledged by the Roman centurion on duty at Golgotha and on his observation of Jesus' death. His pronunciation, 'Truly this man was a Son of God' (Mk 15:39), in fact personified the leadership of Jesus. This exclamation, as explained by Adair (2001:134), may have been nothing more that a soldier's tribute to the extraordinary courage and endurance displayed by Jesus on the cross in the face of 
death, but alternatively also an echo of a belief among the Roman soldiers that everything about Jesus was extraordinary.

The biblical metaphor of the human person as an empty vessel, though useful, is a powerful one, because it acknowledges that Christian leadership is reliant on the grace of God. This reliance is not a sign of weakness, because Paul delights in his weaknesses, as therein resides his strength:

${ }^{9}$ But he said to me, 'My grace is sufficient for you, for my power is made perfect in weakness'. Therefore I will boast all the more gladly about my weaknesses, so that Christ's power may rest on me. ${ }^{10}$ That is why, for Christ's sake, I delight in weaknesses, in insults, in hardships, in persecutions, in difficulties. For when I am weak, then I am strong. (2 Cor 12:9-10)

Those in leadership are often of opinion that strength lies in strength, but such a vessel is already full of personal self-reliance and there is no space for the grace of God: 'My grace is sufficient for you, for power is perfected in weakness' (2 Cor 12:9). The woman, as the so-called 'weaker vessel', need not necessarily be a negative attribute, because it is also the flip side of strength in the sense of drawing on the grace of God to exercise kingdom leadership. This leadership quality of self-giving is an expression of the presence of the 'kingdom of God' and it is believed that women have the natural capacity to embrace qualities such as love and compassionate action by practicing the ability to nurture.

Jesus was the leader-in-chief from the Greek archegos (Ac 3:15; 5:31; Heb 2:10; 12:2) and the archegos is both the source and leader, 'the one who takes the first action and then brings those on whose behalf he has acted to the intended goal' (Adair 2001:137). To this end, Paul (Phlp 2:1-5) wrote that followers of Christ ought to imitate his humility and take on his mindset:

Therefore, if you have any encouragement from being united with Christ, if any comfort from his love, if any, common sharing in the Spirit, if any tenderness and compassion, 2 then make my joy complete by being like-minded, having the same love, being one in spirit and of one mind. 3 Do nothing out of selfish ambition or vain conceit. Rather, in humility value others above yourselves, 4 not looking to your own interests, but each of you to the interests of the others. 5 In your relationships with one another, have the same mindset as Christ Jesus ...

Empty vessel leadership implies 'serve to lead'. The most distinctive aspect of Jesus' leadership and even his teaching on leadership is his emphasis of 'serve to lead'. It is very obvious from the women in the Scriptures that they served and lead in various roles. The concept diakonos, which exemplifies humility, is housed in the answer Jesus provided to the disciples when they asked who was the greatest among them: '... Jesus called the Twelve and said: "Anyone who wants to be first must be the very last, and the servant of all."' (Mk 9: 35)

To be a servant implies that no distinctions would be made as to whom ought to be served or not. The leadership of Jesus does not clamour for greatness as stated in Luke 9:48: '... he who is least among you all is the one who is great'.
In Matthew 20:26 Jesus spells out the new type of leadership he expects from his disciples: 'Whoever would be great among you must be your servant.'

Jesus cites himself as an example, stating according to Mark 10: 45: 'For the Son of Man also came not to be served, but to serve, and to give his life as a ransom for many.'

And in Luke 22: 27: “But I am among you as one who serves.'

These gospel axioms are applicable to both men and women, regardless of the category of leadership. Jesus implores his disciples not to lord it over the people ... but to serve. Jesus was tough and exact about leadership, although he never displayed domineering or overbearing leadership-conduct. In contrast, he advocated servant or shepherd leadership. Humility and meekness (bow before God in Hebrew) are not weak traits of leadership, but it is captured in graceful tenderness - a gentleness that Jesus displayed in his openness as servant of all (Mt 19:13-15; Adair 2001:142). As the leader of his followers, Jesus did not give himself special privileges; he walked alongside his followers, barefooted, with no money, purse or provisions. He slept where the night settled: 'Foxes have holes and birds of the air have nests, but the Son of Man has nowhere to lay his head' (Mt 8:20).

As a leader, Jesus was not foolhardy as he removed himself from threatening situations, but at the same time did not surround himself with bodyguards for protection. A shepherd remains, and a good shepherd lays down his life for his sheep (Jn 10:11-13). This type of leadership is in reach for all vessels, women and men.

\section{Conclusion}

The biblical depiction of a woman as a weaker, but honoured vessel (1 Pt 3:7) needs to be read in its ancient biblical context and ought to be stripped from all negative connotations and interpretations. More emphasis should be placed on the positive aspects such as that the woman should be honoured and respected. Weaker vessel leadership, biblically speaking, also indicates that the power to lead, rest in Christ (2 Cor 10), and this spirit of leadership should be contained by both men and women. This manner of leadership knows how to embrace the pain of division and transcends all earthly constructions, churches, synagogues, mosques, temples and doctrines. Jesus' leadership vision is beyond all earthly perceptions, because he intended to create a civilisation of love, which is built painfully, 'stone by stone, out of human lives prepared to sacrifice all in search for true life and lasting love' (Adair 2001:146). Wherever the bounds of truth, freedom, justice, community, beauty and goodness are enhanced, there a Christian leader is called to realise the Kingdom's values. The higher a person's reputation stands, the more humbleminded the person ought to become, eyes fixed on the good of the whole community, and not on personal gain and favour. 'Love is without servility, as it is without arrogance. Love knows no division, promotes no discord; all the works of love are done in perfect fellowship' (Adair 2001:146). 
The biblical verse, 1 Peter 3:7, should not be used to present the male person and the Godhead in a superior masculine image, but should be emptied from patriarchal characteristics. The self-emptying is a process that should function as a divine corrective to male dominance and a male-imaged God, both in church and society. Kenotic leadership insists that no one is above the other, no one is weaker than the other as the act of Jesus' self-emptying taught us to level the heavens and exalt the earth and create a new environment without masters and slaves, rulers and subjects, weaker vessels and useful vessels. We are all one and on one level of existence, and the woman is equally created in the Image of the Divine; the woman is fully endowed to act in persona Christi, be it in Christian leadership capacities or otherwise. Theological doctrines based on tradition and culture can be brought in line with unadulterated interpretations of Scripture that recognise all people and genders as inclusively equal. Corrective measures concerning the general status of women should be brought into the theological equation and discrepancies based on traditional arguments should be reassessed.

\section{Acknowledgement Competing interest}

The author declares that no competing interest exists.

\section{Author's contribution}

I declare that I am the sole author of this research article.

\section{Ethical consideration}

Ethical clearance was not needed or required for the study, but followed all ethical standards for carrying out research.

\section{Funding information}

No grant or funding was received for this article.

\section{Data availability statement}

Data sharing is not applicable to this article as no new data were created or analysed in this study.

\section{Disclaimer}

The views and opinions expressed in this article are those of the authors and do not necessarily reflect the official policy or position of any affiliated agency of the authors.

\section{References}

Adair, J., 2001, The leadership of Jesus and its legacy today, Canterbury Press, Norwich.

Aquinas, T., 1920, The Summa Theologiæe of St. Thomas Aquinas, 2nd \& rev. edn., literally transl. by Fathers of the English Dominican Province, Part 3 Question 83, of the Rite of this Sacrament, art. I, ad 3:33.

Bott, J., n.d., Leadership styles of prominent figures in the Bible, Faculty of Education, Brock University, Sophia's online courses, viewed 16 September 2019, from https://www.sophia.org/tutorials/leadership-styles-of-prominent-figures-inthe-bibl.

Brown, R., 1970, The anchor Bible: The gospel according to John, Garden City, Doubleday, New York.

Code of Canon Law, 1983, George Basil Hume, ed. \& transl. Collins Liturgical Publications, London.

Doyle, E., 1985-1986, 'The question of women priests and the argument in Persona Christi', The Catholic Citizen 40(Winter); With acknowledgements to the Irish Theological Quarterly 50, 1983-1984, 212-221. https://doi.org/10.1177\% 2F002114008305000408

Ehrensperger, K., 2007, Paul and the dynamics of power: Communication and interaction in the early Christ-movement, Clark, London.

International Standard Bible Encyclopedia (ISBE), 2015, viewed n.d., from https:// www.bible-history.com/.

Liddell, H., Scott, R. \& Jones, H.S., 1996 [1843], LSJ Greek-English Lexicon, Clarendon Press, Oxford.

Pope Benedict XVI, 2007, Holy Chrism Mass: In Persona Christi, Taken from L'Osservatore Romano, Weekly Edition in English, 13 April, p. 2.

Pope Francis, 20 August 2018, 'Letter of His Holiness Pope Francis to the People of God'.

Ratzinger, C.J., 2002, Decree on the attempted ordination of some Catholic women, Congregation for the Doctrine of the Faith, Rome, Vatican City.

Richardson, A. \& Bowden, J., 1989, A new dictionary of Christian theology, SCM Press, London.

Seper, F.C. \& Hamer, J.O.P., 1976, Sacred congregation for the doctrine of the faith declaration inter insigniores on the question of admission of women to the ministerial priesthood, Titular Archbishop of Lorium Secretary, Vatican Press, Rome.

Salaman, E., 1955, 'A talk with Einstein', The Listener 54, 370-371.

Slater, J., 2012, Christian identity characteristics in Paul's letter to the members of the Jesus movement in Galatians, Authorhouse, Bloomington.

Spencer, A.B., 2009, 'A cloud of female witnesses: Women leaders in the New Testament', Journal: Priscilla Papers 23(4), 23-24, viewed 16 September 2019, from https://www.cbeinternational.org/sites/default/files/Cloud_Spencer.pdf.

Wessels, W.J. \& Barentsen, J., 2016, 'Crisis leadership amidst disruptive change: The case of the Prophet Jeremiah', in J. Barentsen, V. Kessler \& E. Meier (eds.), Christian leadership in a changing world: Perspectives from Africa and Europe, $\mathrm{pp}$. 27-43., Peeter, Leuven.

Wijngaards, J., 2001, The ordination of women in the Catholic Church: Unmasking a Cuckoo's egg tradition, Darton, Longman \& Todd, London. 